\title{
BENEFICÊNCIA DO PESQUISADOR: DA CURIOSIDADE AO TECER DO CONHECIMENTO
}

Ana Maria Dyniewicz', Fátima Aparecida Said²

Curiosidade é palavra de raiz latina: cur que significa por quê. O significado convidativo e positivo desta palavra identifica que é muito apropriado se conferir ao pesquisador o status de curioso. Em investigação, o curioso ou pesquisador tem sua motivação ovacionada pelo desejo de conhecer. Inicia-se assim a construção da trajetória pela mais adequada questão a investigar: o problema de pesquisa que atiça o núcleo central de sua usina mental, na busca de sentido(s) para algo ou algum fenômeno que lhe obscurece, provoque ou instigue.

Insatisfeito por não ter um porque claro e objetivo, a ação natural do investigador é ir ao encontro do saber já produzido para conhecê-lo, seja em fontes primárias ou secundárias, para ter um layout do tema. Busca, então, visão ampliada e verifica as cercanias do assunto de sua necessidade. Esta busca tem méritos contemporâneos ao facilitar a vida acadêmica online, com ferramentas e utensílios mais ou menos dominados (ou dominadores) pela diligência do inquiridor estudioso. Para alguns a busca bibliográfica pode expressar lazer, para outros penar, condições estas são permeadas por ações exaustivas, mas compensatórias, pois permitem a redação que delimita o problema, apresenta o estado da arte do assunto e os objetivos do pesquisador.

A saga continua. Põe-se, sequencialmente, a metodologia com questões que urgem por ordenação, lógica, organização, técnica que requererá outras buscas, agora, por métodos que se adéquem às questões inquiridoras. O pesquisador sabe que os estudiosos de tema não são necessariamente os de métodos; conversa, reflete, estuda, discute e se apropria de trajetória metodológica que mais lhe pareça ajustada como vereda definida. Ir a campo para coletar dados é ação estimulante depois de horas de relativo isolamento e pode ser, de modo geral, agradável, lúdico e inquietante, mas não tanto quanto o transcrever ou tabular os dados do instrumento aplicado. Às vezes a ação investigatória é caminho e cenário um tanto solitário.

Discreto, singular e obreiro da arte de pensar e escrever, o pesquisador vai tecendo uma teia de círculos concêntricos que dão lógica, arranjo e regulamento ao tecido escrito. É um tecer e um te-sendo do pesquisador com tempos, cenário e protagonistas. Como sua meta é averiguadora, preza pela ética, tem rigor metodológico e executa sua labuta com calma e perseverança. Rascunhos são recolhidos e guardados, fontes bibliográficas anotadas, conteúdos selecionados, revistos e revisados.

Chega então o momento decisivo, o clímax da pesquisa: o que foi encontrado? Os resultados e as discussões tornam o inquiridor exultante, mas exauri-lo pela exigência acadêmica, pela tomada de decisões cujo raciocínio requer clareza, objetividade, ordenação e fundamentação. Os papéis e anotações se acumulam, junto com a paciência e a persistência.

Redigir as conclusões tem sabor de vitória, mas não para o pesquisador que tem por meta tecer a construção de seu conhecimento. É etapa vencida, é caminho percorrido, pois logo inicia outro e outro, sucessivamente em descobertas que o maravilham diante do mundo, da sociedade, da vida e do futuro. O que, afinal, a curiosidade nos impõe e onde nos põe? Sabedoria, conhecimento sustentado, serenidade e um olhar novo ou de novo. Pela sabedoria desbravamos caminhos, desvelamos dimensões e profundidades, construímos novos saberes, abrimos portas para o futuro, e nos pomos abertos a outras curiosidades.

${ }^{1}$ Enfermeira. Doutora em Enfermagem. Vice-líder do Grupo de Pesquisa em Política, Gestão e Práticas em Saúde-GPPGPS da Universidade Federal do Paraná.

${ }^{2}$ Enfermeira. Pedagoga. Mestre em Enfermagem. 


\title{
THE RESEARCHER'S BENEFICENCE: FROM CURIOSITY TO THE WEAVING OF KNOWLEDGE
}

\author{
Ana Maria Dyniewicz', Fátima Aparecida Said²
}

The word 'curiosity' has a Latin root: cur, which means 'why'. The inviting and positive meaning of this word identifies that it is highly appropriate to confer on the researcher the status of 'curious'. In an investigation, the curious person or researcher's motivation is applauded by the desire to know. Thus begins the construction of the route to the most appropriate question to investigate: the research problem which fires up the central nucleus of her mental power plant, in search of meaning(s) for something or some phenomenon which intrigues, provokes or engages her.

Dissatisfied with not having a clear and objective 'why', the natural action of the investigator is to seek the knowledge already produced so as to become familiar with it, whether from primary or secondary sources, so as to have a grasp of the issue: so she seeks a wider view, and checks the surroundings of the topic of her need. This search has contemporary merits, facilitating academic life through being carried out on-line, with tools and utensils which, through diligence, the studious inquirer can more-or-less dominate (or be dominated by). For some, the literature search can express leisure, for others, punishment, both of which are permeated with actions which are exhausting yet worthwhile, as they allow the editing which delimits the problem, and presents the state of the art on the topic - and the researcher's objectives.

The saga continues. In sequence, the methodology is set up, with questions which demand order, logic, organization, and technique, requiring further searches, now, for methods which are suited to the inquiring questions. The researcher knows that those studying the issue are not necessarily those studying methods; she converses, reflects, studies, discusses and appropriates the methodological trajectory which most seems to her to be adapted as the defined track. To go into the field to collect data is a stimulating action after hours of relative isolation and can be, general speaking, pleasant, entertaining and disquieting, but not so much as transcribing or tabulating the data from the instrument which was administered. Sometimes the investigatory action is a somewhat solitary path and setting.

Unobtrusive, unique and a labourer in the art of thinking and writing, the researcher spins a web of concentric circles which give logic, arrangement and rules to the written matter. It is a weaving, and a weaving of the researcher into, times, settings and protagonists. As the researcher's goal is to verify, she prizes ethics, has methodological rigor, and carries out her toil with calm and perseverance. Rough drafts are gathered and kept, bibliographic sources are noted, content is selected, checked through, and revised.

The decisive moment arrives, the climax of the research: what was found? The results and the discussions exult the inquirer, but exhaust her by the academic rigor and by the decision-making, whose reasoning requires clarity, objectivity, ordering and grounding. The papers and notes accumulate, along with the patience and persistence.

Wording the conclusions has the taste of victory, but not for the researcher whose goal is to weave the construction of her knowledge. It is behind her, it's a beaten path, as soon another begins, and then another, successively, in discoveries which leave her marvelling at the world, society, life and the future. At the end of the day, what does curiosity impose upon us, and whither does it lead us? Wisdom, grounded knowledge, serenity, and a new or renewed perspective. For the sake of knowledges we brave paths, unveil dimensions and depths, build new knowledge, open doors to the future - and open ourselves to other curiosities.

\footnotetext{
${ }^{1}$ Nurse. Doctorate in Nursing. Vice leader of the Policy, Management and Practices in Health Research Group - GPPGPS of the Federal University of Paraná.

${ }^{2}$ Nurse. Educator. Master's degree in Nursing.
}

Cogitare Enferm. 2013 Jan/Mar; 18(1):9-11 


\section{CALIDAD DEL INVESTIGADOR: DE LA CURIOSIDAD AL TEJER DEL CONOCIMIENTO}

Ana Maria Dyniewicz', Fátima Aparecida Said²

La palabra "curiosidad" tiene su raiz en el latín cur que significa por qué. Ese significado, que al mismo tiempo es positivo e invita, identifica que se puede perfectamente conceder al investigador el estatus de curioso. En investigación, el curioso o investigador tiene su motivación aclamada por el deseo de conocer. Ahí se empieza la construcción de la trayectoria por la más adecuada cuestión a investigar: el problema de investigación que incita el núcleo central de su usina mental, en la búsqueda de sentido(s) para algo o algún fenómeno que le oscurece, provoque o instigue.

Insatisfecho por no tener un por que claro y objetivo, la acción natural del investigador es ir al encuentro del saber ya producido para conocerlo, sea en fuentes primarias o secundarias, a fin de tener un layout del tema. De esa forma, busca una visión ampliada y verifica las cercanías del asunto de su necesidad. Tal búsqueda tiene méritos contemporáneos por facilitar la vida académica online, con herramientas y utensilios más o menos dominados (o dominadores) por la diligencia del inquiridor estudioso. Para algunos, la búsqueda bibliográfica se relaciona al ocio, para otros, al penar. Esas condiciones están permeadas por acciones exhaustivas, pero compensatorias, pues permiten la redacción que delimita el problema, presenta el estado del arte del asunto y los objetivos del investigador.

La saga continúa. En la secuencia se depara con la metodología y las cuestiones que necesitan de ordenación, lógica, organización, técnica, lo que requerirá otras búsquedas, ahora, por métodos adecuados a las cuestiones inquiridoras. El investigador sabe que los estudiosos del tema no son necesariamente los de métodos; charla, reflexiona, estudia, discute y se apropia de trayectoria metodológica que más le parezca ajustada como vereda definida. Ir a campo para recoger datos es acción estimulante después de horas de relativo aislamiento y puede ser, de modo general, agradable, lúdico e inquietante, pero no tanto cuanto el transcribir o tabular los datos del instrumento aplicado. Por veces, la acción investigativa son camino y escenario solos.

Discreto, singular e artesano del pensar y escribir, el investigador contruye una tela de círculos concéntricos que dan lógica, orden y reglamento al tejido escrito. Es un tejer y un ser del investigador con tiempos, escenarios y protagonistas. Como su meta es averiguadora, aprecia la ética, tiene rigor metodológico y ejecuta su lucha con tranquilidad y perseverancia. Borradores son recogidos y guardados, fuentes bibliográficas apuntadas, contenidos selecionados y revisados.

Así, llega el momento crucial, el clímax de la investigación: ¿Qué se encontró? Los resultados y las discusiones dejan el inquiridor exultante, pero exhausto por la exigencia académica, por la tomada de decisiones cuyo raciocinio necesita claridad, objetividad, ordenación y fundamentación. Los papeles y apuntes se amontonan, así como la paciencia y la persistencia.

Redactar las conclusiones tiene la sensación de victoria, pero no para el investigador cuya meta es tejer la construcción de su conocimiento. Es etapa vencida, es camino hecho, pues luego empiezan otro y otro, sucesivamente en descrubrimientos que lo maravillan delante del mundo, de la sociedad, de la vida y del futuro. Pero, ¿qué la curiosidad impone y en qué lugar nos pone? Sabiduría, conocimiento sustentado, serenidad y una mirada nueva. Por medio de la sabiduría, hallamos caminos, desvelamos dimensiones y profundidades, construimos nuevos saberes, abrimos puertas para el futuro, y nos quedamos abiertos a otras curiosidades.

${ }^{1}$ Enfermera. Doctora en Enfermería. Vice líder del Grupo de Investigación en Política, Gestión y Prácticas en Salud - GPPGPS de la Universidad Federal de Paraná.

${ }^{2}$ Enfermera. Pedagoga. Maestra en Enfermería. 